\title{
Fuzzy Quantitive Strategic Planning Matrix dalam Perencanaan Strategi Perguruan Tinggi
}

\author{
Fera Tri Wulandari $^{\mathrm{a}}$, Ibnu Widiyanto ${ }^{\mathrm{b}}$ \\ ${ }^{a}$ Universitas Widya Dharma Klaten \\ ${ }^{\mathrm{b} J u r u s a n}$ Manajemen, Fakultas Ekonomika dan Bisnis, Universitas Diponegoro
}

Naskah Diterima : 5 Mei 2014; Diterima Publikasi : 27 Juni 2014

\begin{abstract}
The strategic plan helps the college in determining the direction of the college to achieve a desired future and provides a framework for achieving competitive advantage. In the strategic planning process, the selection of strategies is essential if universities do not have the resources to implement all the strategies. FQSPM designed to determine the relative attractiveness of each alternative strategy using triangular fuzzy numbers. Merger FQSPM and FTOPSIS used in the decision-making process on strategic planning by a college to conduct the election strategy based on the results of internal and external analysis. The results of the strategic planning helps colleges determine the direction to achieve the desired future so that colleges can anticipate environmental changes and predict the risk while continuing to adjust the action with the aim to be achieved college.
\end{abstract}

Keywords: Strategic Planning; SWOT; Fuzzy QSPM; Fuzzy TOPSIS

\begin{abstract}
Abstrak
Rencana strategis membantu perguruan tinggi dalam menentukan arah perguruan tinggi untuk mencapai masa depan yang diinginkan dan menyediakan kerangka kerja untuk mencapai keunggulan kompetitif. Dalam proses perencanaan strategi, pemilihan strategi penting dilakukan jika perguruan tinggi tidak memiliki sumber daya untuk menerapkan semua strategi. FQSPM dirancang untuk menentukan daya tarik relatif setiap strategi alternative dengan menggunakan bilangan fuzzy segitiga. Penggabungan FQSPM dan FTOPSIS digunakan dalam proses pengambilan keputusan pada perencanaan strategi suatu perguruan tinggi untuk melakukan pemilihan strategi berdasarkan hasil analisis internal dan eksternal. Hasil perencanaan strategis tersebut membantu perguruan tinggi menentukan arah untuk mencapai masa depan yang diinginkan sehingga perguruan tinggi dapat mengantisipasi perubahan lingkungan dan memperkirakan resikonya sambil terus menyesuaikan tindakan dengan tujuan yang hendak dicapai perguruan tinggi.
\end{abstract}

Keywords : Perencanaan Strategi; Fakultas; SWOT; Fuzzy QSPM; Fuzzy TOPSIS

\section{Pendahuluan}

Peningkatan permintaan pendidikan tinggi bersamaan dengan perubahan demografi mahasiswa dan kebutuhan untuk bersaing dengan universitas lain mendorong universitas untuk melakukan perencanaan strategis. Proses perencanaan strategis menguntungkan perguruan tinggi di berbagai hal dan dapat membantu mempersiapkan universitas untuk menghadapi berbagai tantangan. Hasil dari perencanaan strategis membantu universitas untuk menyediakan kerangka kerja untuk mencapai keunggulan kompetitif, menentukan arah sebuah universitas untuk mencapai masa depan yang diinginkan, memungkinkan komunikasi antara komponen universitas untuk berpartisipasi dan bekerja sama menuju pencapaian tujuan dan meningkatkan pemahaman organisasi visi (Lerner, 1999).

\footnotetext{
*) Penulis korespondensi: per_roll@yahoo.com
}

Pengembangan rencana strategis melalui proses manajemen strategis harus dilakukan secara metodologis dan sistematis (Shawyun, 2010). Untuk melakukan perencanaan strategis, perguruan tinggi perlu menyesuaikan model strategi bisnis untuk pendidikan tinggi karena perencanaan strategis universitas berbeda dari model bisnis. Pedoman Universitas yaitu investasi jangka panjang dalam mendidik orang memerlukan pendekatan yang berbeda dalam perencanaan strategis di universitas. Model perencanaan strategis Universitas biasanya memakan waktu 5 tahun atau lebih (Lerner, 1999). Proses manajemen strategis memiliki tiga fase utama yaitu analisis strategis, perumusan strategi dan pelaksanaan strategis (Shawyun, 2010). Prosesproses utama mencakup pengembangan rencana strategis melalui analisis lingkungan internal dan eksternal. Berdasarkan pada dua analisis utama tersebut, hasil utama adalah seperangkat strategi SWOT dan identifikasi Isu strategis. Berdasarkan 
analisis ini, strategi dapat dikembangkan, dievaluasi dan dipilih yang akhirnya akan mengarah pada strategi yang diterapkan dengan QSPM.

Analisis SWOT dan model QSPM telah digunakan untuk formulasi strategi pada rental komputer (David et al., 2009). QSPM juga digunakan dalam merumuskan sebuah strategi untuk sebuah perusahaan pelumas (Saghei et al., 2012), pada perusahaan genting (Nasab dan Milani, 2012) dan pada formulasi strategi Institusi Pendidikan Tinggi Saam (Shojaie, 2012).

Dalam proses pengambilan keputusan MADM digunakan untuk menampung beberapa alternatif dan kriteria. Pengambilan keputusan dengan logika pemrograman metode Fuzzy Multi Attribute Decision Making - Technique for Order Preference by Similarity to Ideal Solution (FMADM-TOPSIS) diterapkan pada model evaluasi Business Intellegence untuk sistem enterprise (Rouhani et al., 2011). FMADM-TOPSIS juga digunakan dalam proses seleksi investasi saham (Madi dan Osman, 2011) dan pemilihan lokasi gudang (Ashrafzadeh, 2012).

Penggabungan FQSPM dan FTOPSIS diharapkan bisa menjadi salah satu metode yang dapat digunakan dalam pengambilan keputusan pada proses perencanaan strategi suatu fakultas berdasarkan hasil analisis internal dan eksternal fakultas. Melalui perencanaan strategi dapat mengantisipasi perubahan lingkungan dan memperkirakan resikonya sambil terus menyesuaikan tindakan/aktifitas dengan tujuan yang hendak dicapai fakultas.

\section{Kerangka Teori}

\subsection{Perencanaan Strategi Bisnis}

Strategi adalah alat bagi universitas untuk menemukan keunggulan dan tempat kompetitif dalam lingkungan. Manajemen strategi didefinisikan sebagai seni dan pengetahuan untuk merumuskan, mengimplementasikan dan mengevaluasi suatu keputusan sehingga mampu mencapai tujuan bisnis (David et al., 2009). Menurut Shawyun (2010) proses manajemen strategis terdiri dari tiga tahapan yaitu: analisa kondisi organisasi, formulasi strategi dan implementasi strategi. Proses-proses utama mencakup pengembangan Rencana Strategis melalui analisis lingkungan internal dan eksternal. Perencanaan strategis merupakan salah satu langkah utama yang dapat dilakukan universitas untuk mengatasi tantangan. Universitas harus menyusun rencana strategis yang efektif untuk mengembangkan sumber daya manusia (Shawyun, 2010).

McNamara (2011) menyatakan bahwa tidak ada satupun model perencanaan yang sempurna. Apa yang dipilih oleh sebuah organisasi didasarkan pada tujuan dari perencanaan strategis, apakah organisasi telah melakukan perencanaan sebelumnya, budaya organisasi, perubahan lingkungan organisasi dan keberhasilan dalam perencanaan organisasi.
McNamara (2011) mengidentifikasi 6 model dari perencanaan strategis yang suatu organisasi dapat memilih untuk menggunakannya ketika organisasi tersebut memulai perencanaan strategis sebagai berikut:

a. Model Satu - perencanaan strategis berbasis Visi atau tujuan biasanya dilakukan oleh sebuah organisasi kecil yang tidak melakukan perencanaan apapun di masa lalu untuk memulai proses perencanaan strategis keseluruhan untuk memastikan arah yang pasti.

b. Model Dua - Masalah berbasis perencanaan yang dilakukan oleh organisasi dengan sumber daya terbatas dan segera ingin dicapai.

c. Model Tiga - Penyelarasan Model dengan tujuan yang selaras dengan misi dan sumber daya yang secara efektif beroperasi di organisasi.

d. Model Empat - Skenario perencanaan yang biasanya digunakan dalam hubungannya dengan model lainnya untuk melakukan pemikiran strategis dan mengidentifikasi isu-isu strategis dan tujuan.

e. Model Lima - perencanaan mengorganisir diri yang merupakan pendekatan tradisional yang terlihat pada mekanisme umum ke spesifik atau sebab-akibat dari penilaian yang luas dan analisis lingkungan yang mengarah ke satu set alternatif

f. Model Enam - perencanaan real time menegaskan perencanaan yang harus dilakukan terus menerus menyesuaikan dengan keadaan dan perubahan lingkungan yang cepat

\subsection{Kerangka SAFER}

Kerangka SAFER (the Strategic Alternatives Formulation, Evaluation and Recommendation) menghubungkan dua tahap analisis strategis dan perumusan strategis. Kerangka SAFER dirancang untuk merumuskan, mengevaluasi dan merekomendasikan strategi yang sesuai organisasi dapat digunakan untuk melanjutkan posisinya di industry. Tiga tahapan utama dari kerangka SAFER menurut Shawyun (2010) yaitu:

1. Tahap 1: Tahap Input, hasil dari analisis lingkungan internal dan eksternal yang digunakan. Data masukan berasal dari Faktor Analisis Lingkungan Strategis.

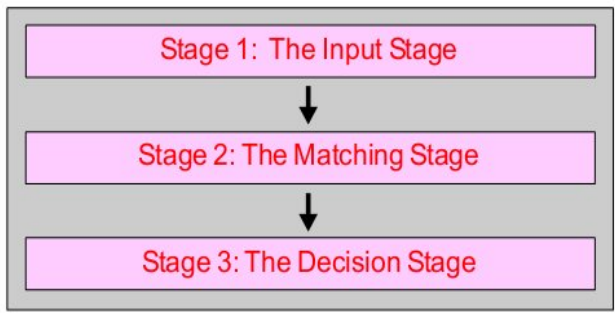

Gambar 1. Tahapan dalam Kerangka SAFER

2. Tahap 2: Tahap Matching. Setelah Strategis SWOT telah diidentifikasi, komponen kunci dari 
SW dan WT dicocokkan untuk memastikan bahwa dirumuskan strategi didasarkan pada kemampuan yang sedang digunakan atau diciptakan untuk memanfaatkan peluang. Pada saat yang sama, kelemahan dan ancaman harus diperhitungkan dan ditangani

Setelah strategis SWOT dan isu-isu strategis telah diidentifikasi dari Analisis Strategic, langkah berikutnya adalah merumuskan strategi sendiri. Pengembangan strategi ini mendefinisikan program tindakan pada tiga level. Ketiga tingkatan strategi dapat diringkas sebagai berikut:

a. Strategi tingkat korporasi atau organisasi: strategi utama untuk seluruh HEI atau sekolah dalam rangka untuk menentukan apa dan bagaimana ingin mencapai visinya, misi, tujuan dan sasaran.

b. Strategi tingkat kompetitif atau bisnis: strategi di tingkat unit bisnis atau strategi kunci dari kelompok produk pendidikan. Ini harus disesuaikan dengan strategi perusahaan atau tingkat organisasi dan menentukan strategi kompetitif apa dan bagaimana untuk bersaing dalam pasar tertentu.

c. Strategi tingkat fungsional: strategi operasional utama dalam mendukung tingkat bisnis atau strategi kompetitif yang akan dilaksanakan dan dicapai oleh semua bidang fungsional utama sejalan dengan bisnis dan strategi perusahaan.

3. Tahap 3: Tahap Keputusan, setelah strategi telah dirumuskan, diidentifikasi atau dikembangkan, kemudian strategi tersebut harus dievaluasi untuk memilih strategi yang paling yang sesuai bagi organisasi. Pemilihan ini penting jika organisasi tidak memiliki sumber daya untuk menerapkan semua strategi. Dengan demikian, universitas harus memilih strategi yang yang paling layak, praktis dan tepat berdasarkan keadaan dari organisasi.

QSPM menentukan daya tarik relatif dari berbagai strategi yang dibangun berdasarkan faktorfaktor keberhasilan penting eksternal dan internal (David, 2012). Menurut Nasab dan Melani (2012), pada prinsipnya komponen dasar dari QSPM adalah: (1) daftar faktor internal dan eksternal kunci, (2) strategi yang akan dievaluasi, (3) penilaian, (4) nilai attractiveness, (5) nilai total attractiveness dan (6) jumlah skor total attractiveness.

\subsection{Fuzzy}

Himpunan kabur (fuzzy set) adalah kelas objek dengan nilai keanggotaan yang kontinu. Ditandai dengan fungsi keanggotaan (karakteristik) yang diberikan ke setiap objek kelas keanggotaan berkisar antara nol dan satu (Zadeh, 1965). Himpunan fuzzy convex memiliki nilai keanggotaan dengan derajat keanggotaan senantiasa monoton (naik/turun), atau memiliki derajat keanggotaan yang monoton naik kemudian monoton turun (Ross, 2005). Semesta pembicaraan pada variabel fuzzy dan domain pada himpunan fuzzy merupakan himpunan bilangan real yang senantiasa naik (bertambah) secara monoton dari kiri ke kanan. Nilai semesta pembicaraan atau domain dapat berupa nilai positif atau negatif. Adakalanya nilai semesta pembicaraan atau domain ini dibatasi batas atasnya (Kusumadewi et al., 2005). Beberapa definisi penting dasar fuzzy set (Amiri, 2010) sebagai berikut:

a. Sejumlah fuzzy segitiga dapat didefinisikan dengan bilangan fuzzy segitiga $\left(a_{1}, a_{2}, a_{3}\right)$. Fungsi keanggotaan $\mu_{\tilde{\Omega}}[x]$ didefinisikan sebagai

berikut:

$$
\mu_{a}[x]=\left\{\begin{array}{lc}
\frac{x-a_{1}}{a_{2}-a_{1}} ; & x \leq a_{1} \\
\frac{a_{3}-x}{a_{3}-a_{2} ;} ; & a_{1}<x \leq a_{2} \\
0 ; & x \geq a_{3} \leq x \leq a_{3}
\end{array}\right.
$$

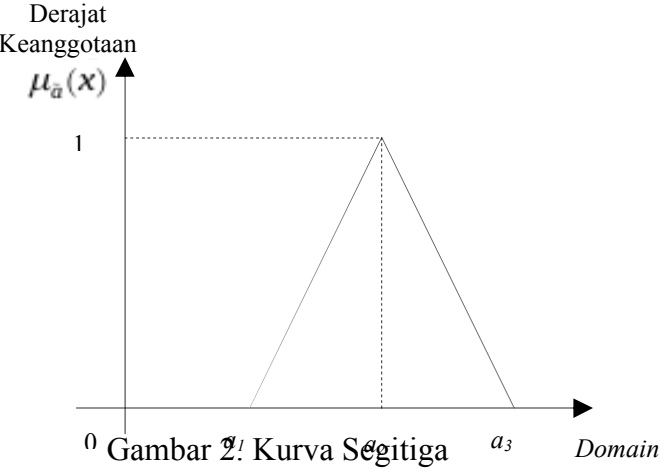

b. Jika yang dua bilangan fuzzy segitiga yang masing-masing ditunjukkan oleh $\left(a_{1}, a_{2}, a_{3}\right)$ dan $\left(b_{1}, b_{2}, b_{3}\right)$, maka hukum operasional dari dua bilangan fuzzy segitiga adalah sebagai berikut:

$$
\begin{aligned}
& \tilde{a}(+) \tilde{b}=\left(a_{1}+b_{1}, a_{2}+b_{2}, a_{3}+b_{3}\right) \\
& \tilde{a}(-) \tilde{b}=\left(a_{1}-b_{1}, a_{2}-b_{2}, a_{3}-b_{3}\right) \\
& \tilde{a}(x) \tilde{b}=\left(a_{1} x b_{1}, a_{2} x b_{2}, a_{3} x b_{3}\right) \\
& \tilde{a}(j) \tilde{b}=\left(a_{1} / b_{1}, a_{2} / b_{2}, a_{3} / b_{3}\right) \\
& k \tilde{a}=\left(k a_{1}, k a_{2}, k a_{3}\right)
\end{aligned}
$$

c. Sebuah variabel linguistik yang hadir dengan kata-kata seperti penggunaan yang sangat rendah, rendah, sedang, tinggi, sangat tinggi untuk menggambarkan kondisi yang kompleks (Zadeh, 1975). Nilai-nilai linguistik juga dapat direpresentasikan oleh bilangan fuzzy (Amiri, 2010).

d. Jika $\tilde{a}$ dan $\hat{b}$ yang dua bilangan fuzzy segitiga yang telah ditunjukkan oleh triplet masing- 
masing $\left(a_{1}, a_{2}, a_{3}\right)$ dan $\left(b_{1}, b_{2}, b_{3}\right)$, maka metode vertex digunakan untuk menentukan jarak antara a dan b adalah:

$d\left(\alpha_{t}, b\right)=\sqrt{\frac{1}{3}}\left[\left(a_{1}-b_{1}\right)^{2}+\left(a_{2}-b_{2}\right)^{2}+\left(a_{a}-b_{3}\right)^{2}\right]$

e. Matriks keputusan tertimbang dari hasil normalisasi dengan fuzzy dibuat dari formula di bawah ini:

$$
\begin{aligned}
& \tilde{v}=\left\lfloor\tilde{v}_{i j}\right]_{4: \ldots j} \\
& \hat{v}_{i j}=\tilde{x}_{i j} x W_{i}
\end{aligned}
$$

Dengan $i=1,2, \ldots . . n$ dan $j=1,2, \ldots . . . m$

Satu set presentasi rating alternatif $A_{j}=(j=1,2, \ldots, m)$ dengan kriteria $C_{i}=(i=1,2, \ldots, n)$. Satu set bobot pentingnya setiap kriteria $W_{i}$ dengan $i=1,2 \ldots . . n$ dan $\hat{x}=\left(\bar{x}_{i j}, i=1,2, \ldots, n, j=1,2, \ldots, m\right)$

\subsection{Fuzzy TOPSIS}

TOPSIS adalah metode beberapa kriteria untuk mengidentifikasi solusi dari satu set alternatif terbatas (Ashtiani et al., 2009). Prinsip dasarnya adalah bahwa alternatif yang dipilih harus memiliki jarak terpendek dari solusi ideal positif dan jarak terjauh dari solusi ideal negatif. Dalam TOPSIS, rating kinerja dan bobot kriteria tersebut diberikan sebagai nilai crisp. Salah satu masalah dari TOPSIS tradisional adalah penggunaan nilai crisp dalam proses evaluasi. Kesulitan lain untuk menggunakan nilai crisp adalah bahwa beberapa kriteria yang sulit diukur oleh nilai-nilai crisp, sehingga selama evaluasi kriteria ini biasanya diabaikan (Wang dan Elhag, 2006).

Keuntungan utama dari TOPSIS dibanding dengan Metode MADM lainnya dalam pengambilan keputusan masalah yang kompleks adalah mudah digunakan, dapat memperhitungkan semua jenis kriteria (subyektif dan obyektif), logika rasional dan mudah dipahami bagi para praktisi, perhitungan proses sangat mudah, konsep memungkinkan mengejar kriteria alternatif terbaik digambarkan dalam matematika secara sederhana, dan bobot penting dapat dimasukkan dengan mudah (Nasab dan Melani, 2012).

Penggunakan bilangan fuzzy segitiga untuk fuzzy TOPSIS karena kemudahan dalam menghitung menggunakan bilangan fuzzy segitiga pada proses pengambilan keputusan. Selain itu, telah diverifikasi bahwa pemodelan dengan bilangan fuzzy segitiga merupakan cara yang efektif untuk formulasi masalah keputusan dengan informasi yang tersedia bersifat subjektif dan tidak akurat (Rouhani et al., 2012).

Pengambilan keputusan multi kriteria dari suatu masalah yang memiliki $n$ alternatif $A_{1}, A_{2}, \ldots, A_{n} \quad$ dan $m$ kriteria
$C_{1}, C_{2}, \ldots, C_{m}$ yang setiap alternatif dievaluasi sehubungan dengan $m$ kriteria (Ashtiani et al., 2009). Semua nilai-nilai/peringkat ditugaskan untuk sejumlah alternatif dengan matriks keputusan dilambangkan dengan $X\left(x_{i j}\right)_{n \times m}$. Dengan $W=\left(w_{1}, w_{2}, \ldots, w_{m}\right)$ menjadi vektor bobot kriteria dan memenuhi $\sum_{j=1}^{m} w_{j}=1$.

Langkah-langkah metode FTOPSIS (Rouhani et al., 2012) sebagai berikut:

a. Memilih nilai linguistik $\breve{x}_{i j}$ untuk alternatif mengenai kriteria. Rating linguistik fuzzy $\breve{X}_{i j}$ membuat rentang normal bilangan fuzzy segitiga yaitu $[0,1]$, maka tidak ada kebutuhan untuk normalisasi.

b. Menghitung matriks keputusan normalisasi $\tilde{V}_{i j}=\tilde{x}_{i j} \times w_{i}$

c. Menentukan solusi ideal positif dan solusi ideal negative dari persamaan berikut:

$A^{*}=\left\{V^{i}{ }_{1} \ldots . V^{*}{ }_{i}\right\}$

$=\left\{\left(\max \hat{V}_{i j} \mid i \in \Omega v\right),\left(\min \hat{V}_{i j} \mid i \in \Omega c\right)\right\}$

$A^{-}=\left\{V^{-}{ }_{1} \ldots V^{-}{ }_{i}\right\}$

$=\left\{\left(\min \tilde{V}_{i j} \mid i \in \Omega b\right),\left(\max \tilde{V}_{i j} \mid i \in \Omega c\right)\right\}$

d. Menghitung jarak setiap alternatif dari solusi ideal dengan persamaan berikut:

$D_{i}^{*}=\sum_{j=1}^{m} d\left(\tilde{V}_{i j} A^{m}\right)$

$D_{i}^{-}=\sum_{j=1}^{m} d\left(\tilde{V}_{i j}, A^{-}\right)$

Dengan $i=1,2 \ldots n$

e. Menghitung kesamaan dengan solusi ideal:

$F C_{i}=\frac{D_{i}^{-}}{D_{i}^{-}+D_{i}^{*}}$

Nilai preferensi terbesar menunjukkan bahwa alternatif menjadi lebih terpilih.

\section{Metodologi}

Meskipun setiap proses perencanaan strategis secara unik dirancang agar sesuai dengan kebutuhan spesifik dari universitas tertentu, setiap model dari perencanaan strategis dimulai dengan mengidentifikasi visi dan misinya. Setelah ini ditetapkan dengan jelas, dilanjutkan ke serangkaian analisis, termasuk eksternal, internal dan benchmarking, yang memberikan konteks untuk mengembangkan isu-isu strategis organisasi. Berikutnya melakukan formulasi strategis dan organisasi mengembangkan strategi khusus termasuk tujuan strategis, rencana aksi, dan taktik. Langkah- 
langkah perumusan strategi dengan FQSPM sebagai berikut:

a. mendaftar kunci peluang dan ancaman eksternal dan strategis perusahaan serta mendaftar kunci kekuatan dan kelemahan internal dan strategis perusahaan.

b. Menetapkan bobot $(w)$ untuk setiap faktor penting keberhasilan eksternal dan internal.

c. Melakukan pencocokan dan mengidentifikasi strategi-strategi alternatif yang organisasi harus mempertimbangkan untuk menerapkan.

d. Menentukan Skor Daya Tarik (AS) dan mengubahnya menjadi bilangan fuzzy segitiga $\mathscr{X}_{i j}$

$\tilde{x}_{i j}=\left(a_{1}, a_{2}, a_{3}\right)$

Pada nilai AS tersebut terdiri dari lima bilangan fuzzy yaitu tidak ada relasi, tidak menarik, agak menarik, cukup menarik dan sangat menarik yang ditunjukkan pada tabel 2. Hasil perhitungan AS tiap kriteria alternatif strategi terlihat pada tabel 1 .

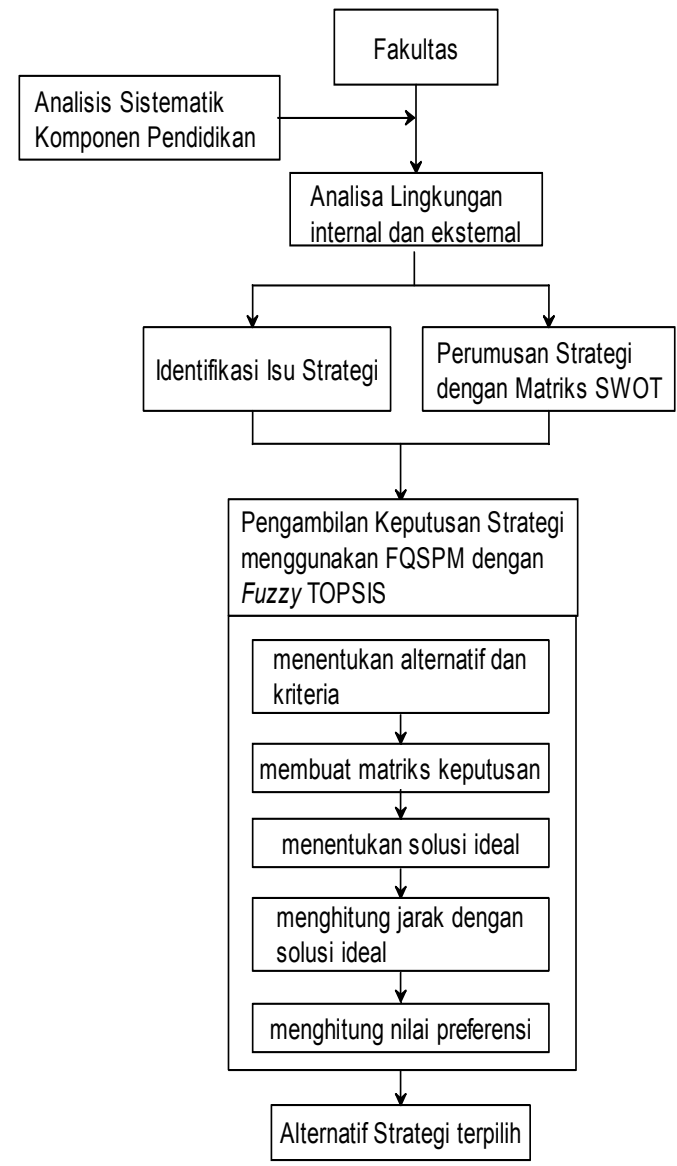

Gambar 3. Perumusan strategi dengan FQSPM
Tabel 2. Bilangan fuzzy Attractiveness Score

\begin{tabular}{lc}
\hline \multicolumn{1}{c}{ Kondisi } & Bilangan Fuzzy \\
\hline Sangat Menarik (SM) & $(0.75,1.00,1.00)$ \\
Cukup Menarik (CM) & $(0.50,0.75,1.00)$ \\
Agak Menarik (AM) & $(0.25,0.50,0.75)$ \\
Tidak Menarik (TM) & $(0.00,0.25,0.50)$ \\
Tidak Ada Relasi (TAR) & $(0.00,0.00,0.25)$ \\
\hline
\end{tabular}

a. Membuat matriks keputusan ternormalisasi dengan mengalikan nilai AS dalam bilangan fuzzy segitiga $\left(a_{1}, \alpha_{2}, a_{3}\right)$ dengan nilai bobot tiap elemen faktor yang merupakan turunan dari persamaan 6 dan 10 .

$$
\tilde{V}_{i j}=\tilde{x}_{i j} \times w_{i}=\left(w a_{1}, w a_{2}, w a_{3}\right)
$$

b. Menentukan solusi ideal positif dan solusi ideal negative sesuai dengan persamaan berikut:

$$
\begin{aligned}
& A^{*}=\left\{V^{*}{ }_{1} \ldots V_{i}^{*}\right\} \\
& =\left\{\left(\max \hat{V}_{i j} \mid i \neq \Omega h\right),\left(\min \tilde{V}_{i j} \mid i \in \Omega c\right)\right\} \\
& A^{-}=\left\{V^{-}{ }_{1} \ldots V^{-}{ }_{i}\right\} \\
& \left.\left.=\left\{\left(\min \tilde{V}_{i j}\right\} i \in \Omega b\right),\left(\max \tilde{V}_{i j}\right\} i \in \Omega c\right)\right\}
\end{aligned}
$$

$\Omega_{\varepsilon}$ adalah set kriteria faktor kekuatan dan peluang dan $\Omega_{e}$ adalah set kriteria factor kelemahan dan ancaman.

c. Menghitung jarak dari setiap nilai alternatif dengan solusi ideal positif dan negatif dengan dengan persamaan berikut:

$$
\begin{aligned}
& D_{i}^{*}-\sum_{j=1}^{m} d\left(\tilde{V}_{i j}, A^{*}\right) \\
& D_{i}^{-}=\sum_{j=1}^{m} d\left(\tilde{V}_{i j}, A^{-}\right)
\end{aligned}
$$

Dengan $i=1,2, \ldots n$

$\left(a_{1}, a_{2}, a_{3}\right)$ adalah nilai kriteria masing-masing elemen faktor

$\left(b_{1}, b_{2}, b_{3}\right)$ adalah nilai solusi ideal dan

$d(\tilde{a}, \bar{b})=\sqrt{\frac{1}{3}}\left[\left(a_{1}-b_{1}\right)^{2}+\left(a_{2}-b_{2}\right)^{2}+\left(a_{3}-b_{3}\right)^{2}\right]$

d. Menghitung kesamaan dengan solusi ideal dengan persamaan berikut:

$$
F C_{i}=\frac{D_{i}^{-}}{D_{i}^{-}+D_{i}^{*}}
$$

Nilai preferensi terbesar menunjukkan bahwa alternatif menjadi lebih terpilih. Alternatif strategi terpilih bisa menjadi bahan pertimbangan untuk manajemen dalam melakukan strategi yang tepat untuk organisasi tersebut. 


\section{Hasil dan Pembahasan}

Perencanaan strategis pada kasus ini menggunakan perencanaan model empat dengan melakukan pemikiran strategis dan mengidentifikasi isu-isu strategis dan tujuan. Setelah mengetahui visi dan misi dari fakultas, selanjutnya melakukan evaluasi faktor internal dan eksternal fakultas yang mengacu pada komponenen sistematik fakultas yang telah menjadi tujuh standar fakultas yang telah ditetapkan oleh DIKTI.

Setelah evaluasi lingkungan internal dan eksternal fakultas selanjutnya dilakukan penentuan alternatif strategi bagi fakultas dengan analisis SWOT dan isu strategis. Alternatif strategi berdasarkan yang sesuai dengan keadaan lingkungan fakultas dan dapat diterapkan di fakultas antara lain:

a. Meningkatkan kualitas pengelolaan administrasi

b. Meningkatkan kinerja pengelolaan keuangan

c. Meningkatkan daya saing alumni

d. Meningkatkan Citra Fakultas

Tahap terakhir dalam perumusan strategi adalah tahap keputusan dengan menggunakan FQSPM yang memungkinkan para penyusun strategi mengevaluasi berbagai strategi alternatif secara objektif berdasarkan faktor-faktor keberhasilan penting yang telah diidentifikasi baik eksternal dan internal. Untuk melakukan perankingan strategi dilakukan dengan menggunakan fuzzy TOPSIS dengan mempertimbangkan nilai dari setiap elemen faktor.

Tabel 2. Bobot kriteria

\begin{tabular}{llc}
\hline & \multicolumn{1}{c}{ Kriteria } & Bobot \\
\hline C1 & Jumlah calon mahasiswa & 0,0514 \\
C2 & minat masyarakat untuk menyekolahkan & 0,0544 \\
C3 & Kebutuhan tenjaga kerja dari bidang IT & 0,0574 \\
C4 & Pegawai meneruskan kuliah jenjang S1 & 0,0604 \\
C5 & Perkembangan teknologi informasi & 0,0483 \\
C6 & perebutan calon mahasiswa dengan & 0,0483 \\
C7 & perguruan tinggi lain & 0,0453 \\
C8 & imaga saing anatar perguruan tinggi & 0,0453 \\
C9 & tinggi & 0,0423 \\
C10 & Tantutan profesionalisme lulusan gedung milik sendiri & 0,0544 \\
C11 & Lokasi strategis & 0,0574 \\
C12 & Perguruan Tinggi paling besar di & 0,0514 \\
C13 & kabupaten Klaten & 0,0483 \\
C14 & Adaya kuliah relatif terjangkau kelas malam dan sore & 0,0604 \\
C15 & Suasana akademis \\
C16 & $\begin{array}{l}\text { Profesionalisme dan kesejahteraan Dosen } \\
\text { dan karyawan }\end{array}$ & 0,0514 \\
C17 & $\begin{array}{l}\text { Fasilitas Sarana dan prasarana proses } \\
\text { belajar mengajar. }\end{array}$ & 0,0544 \\
C18 & Kemampuan daya saing lulusan & 0,0604 \\
C19 & Sistem penjaminan mutu yang ditetapkan & 0,0483 \\
\hline TOTAL & oleh lembaga & 0,0604 \\
\hline & $\quad 1,0000$ \\
\hline
\end{tabular}

Strategi alternatif tersebut akan dihitung tingkat kemenarikannya dengan menggunakan AS berdasarkan faktor analisa internal dan eksternal.
Hasil survei yang dilakukan ke level decision maker digunakan untuk proses penentuan AS. AS ditentukan oleh masing-masing responden dengan melihat alternative strategi secara bersamaan dan menentukan keterkaitan dan daya tarik strategi. Nilai AS setiap elemen faktor ditampilkan pada tabel 3 dan diubah ke bilangan fuzzy segitiga sesuai dengan ketentuan pada tabel 2 . Selanjutnya membuat matriks ternormalisasi dengan melakukan perkalian antara nilai AS dan nilai bobot dari tiap elemen faktor yang menacu pada persamaan 17 yang hasilnya berupa bilangan fuzzy segitiga. Matriks keputusan dan matriks keputusan ternormalisasi dapat dilihat pada lampiran.

$$
\begin{aligned}
& \tilde{V}_{11}=\tilde{x}_{11} \mathrm{r} w_{1} \\
& \tilde{V}_{11}=(0.3750,0.6250,0.8125) \times 0.0079= \\
& (0.0030,0.0049,0.0064)
\end{aligned}
$$

a. Solusi ideal positif dan solusi ideal negatif

Nilai matriks keputusan digunakan untuk menentukan solusi ideal positif dan solusi ideal negatif yang mengacu pada persamaan 18 dan 19. Solusi ideal positif diperoleh dengan memilih nilai terbesar dari elemen faktor kunci sukses dan peluang, serta nilai terkecil dari elemen ancaman. Sebaliknya, Solusi ideal positif diperoleh dengan memilih nilai terkecil dari dari elemen faktor kunci sukses dan peluang, serta nilai terbesar dari elemen ancaman. Hasil penentuan solusi ideal dapat dilihat pada lampiran.

$$
\begin{aligned}
& A_{1}^{*}=\pi r^{2}=V^{*} V_{1, \ldots} V_{11}^{*}= \\
& \left\{\left(\max \nabla_{i j} \mid i \in \Omega b\right),\left(\min \nabla_{i j} i \in \Omega c\right)\right\}= \\
& \max [(0.0030,0.0049,0.0064), \ldots(0.0010,0.0030,0.0049)]= \\
& (0,0030,0,0049,0,0064) \\
& \begin{array}{l}
\left.A_{i}^{-}=\left\{V_{1}^{-} \ldots V^{-}\right]\right\}= \\
\left\{\left(\min V_{i j} \mid i \in \Omega b\right)^{11}\left(\max V_{i j} \mid i \in \Omega c\right)\right\}=
\end{array} \\
& \min \left[(0,0030,0.0049,0.0064)_{n},(0.0010,0,0030,0.0049)\right]= \\
& (0.0010,0.0030,0.0049)
\end{aligned}
$$

b. Jarak antara nilai dari setiap alternatif dengan solusi ideal

Nilai dari matriks keputusan dan solusi ideal digunakan untuk menentukan jarak antara nilai dari setiap alternatif dengan solusi ideal positif dan solusi ideal negatif dengan menggunakan persamaan 20 dan 21. Hasil perhitungan jarak dalam bilangan crisp.

$$
\begin{aligned}
& D_{1}^{*}=E_{m-1}^{n} d\left(\hat{V}_{p}, A^{*}\right) \quad i=1,2, \ldots 19= \\
& 2\left[(0.0030-0.0030)^{2}+(0.0049-0.0049)^{2}+(0.0064-0.0064)^{2}\right]+ \\
& + \\
& {\left[(0.0044-0.0000)^{2}+(0.0079-0.0000)^{2}+(0.0035-0.0119)^{2}\right]=} \\
& 0.0000+0,00157+\ldots+00037=0471341
\end{aligned}
$$




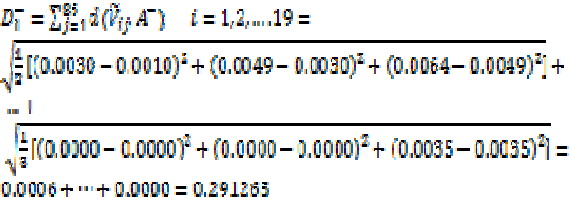

Berdasarkan nilai dari perhitungan jarak setiap alternatif strategi, jarak terpendek dari solusi ideal positif adalah strategi4 dengan nilai 0,2040 dan jarak terjauh dari solusi ideal negatif adalah strategi4 dengan nilai 0,2671 . Nilai preferensi masing-masing alternatif strategi diperoleh dalam bilangan crisp. Nilai preferensi dihitung dengan menggunakan persamaan 23. Alternatif strategi yang dipilih adalah alternatif strategi yang memiliki nilai preferensi terbesar atau jarak terpendek dari solusi ideal positif dan jarak terjauh dari solusi ideal negatif.

$$
F C_{1}=\frac{Z_{2}}{\sigma_{1}+\sigma_{1}}=\frac{0.271}{0.2771+0.1804}=0.4022
$$

Hasil perhitungan nilai preferensi ditampilkan pada tabel 6 dan grafik hasil perangkingan ditampilkan pada gambar 5 .

Tabel 6. Jarak nilai setiap alternatif dengan solusi ideal

\begin{tabular}{lccc}
\hline Strategi & $D^{*}$ & D- & FC- \\
\hline Strategi 1 & 0,2771 & 0,1864 & 0,4022 \\
Strategi 2 & 0,3182 & 0,1479 & 0,3174 \\
Strategi 3 & 0,2291 & 0,2363 & 0,5078 \\
Strategi 4 & 0,2040 & 0,2671 & 0,5670 \\
\hline
\end{tabular}

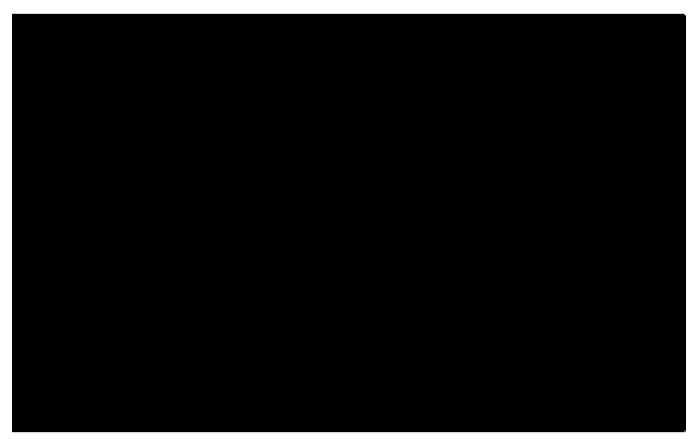

Gambar 4. Jarak nilai setiap alternatif dan solusi ideal

Berdasarkan nilai dari perhitungan jarak setiap alternatif strategi, jarak terpendek dari solusi ideal positif adalah strategi4 dengan nilai 0,2040, jarak terjauh dari solusi ideal negatif adalah strategi4 dengan nilai 0,2671 dan nilai preferensi tertinggi yaitu strategi 4 dengan nilai preferensi 0,5670 . Sehingga dapat disimpulkan bahwa strategi terpilih adalah strategii 4 "meningkatkan Citra Fakultas".

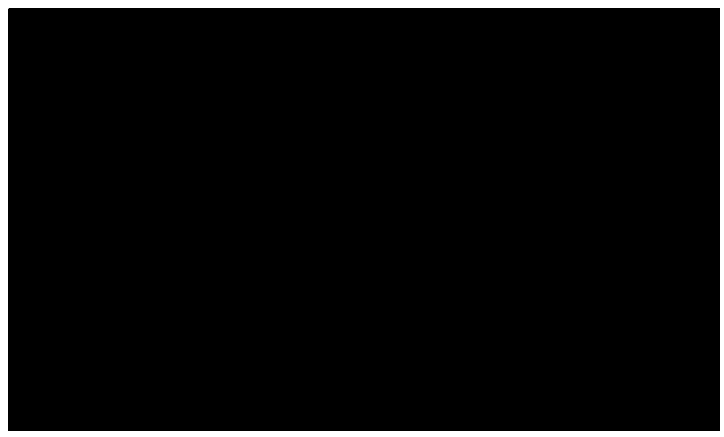

Gambar 5. Hasil Perangkingan

\section{Kesimpulan}

Penggabungan metode Fuzzy QSPM dan Fuzzy TOPSIS digunakan dalam membuat keputusan strategi bisnis pada perguruan tinggi dengan proses pengambilan keputusan strategi bisnis dengan melakukan proses perangkingan alternatif strategi bisnis dari hasil analisa pada tahap sebelumnya. Proses perencanaan strategi diawali dengan analisis lingkungan internal dan eksternal, selanjutnya dilakukan penentuan alternatif strategi bagi fakultas dengan analisis SWOT. Bersadarkan hasil perhitungan yang dilakukan dalam penyusunan FQSPM dalam proses pengambilan keputusan bisnis pada studi kasus, strategi ke empat menempati ranking pertama dengan nilai preferensi tertinggi, yaitu 0,5670 .

\section{Daftar Pustaka}

Amiri, M.P., 2010. Project selection for oil-.elds development by using AHP and fuzzy TOPSIS methods. Expert System with Application, 37, 6218-6224

Ashrafzadeh, M., Rafei, F.M., Zare, Z., 2012. Aplication of fuzzy TOPSIS method for the selection of warehouse location: a case study. Interdisciplinary Journal of Contemporary Research in Business, Vol.3 No.9, 655-667.

Ashtiani, B., Haghighirad, F., Makui, A., Montazer, G.A., 2008. Extension of fuzzy TOPSIS method based on interval-valued fuzzy sets. Applied Soft Computing. Vol. 9, No.2, 457-461

David, M.E., David, F.R., David, F.R., 2009. The quantitative strategic planning matrix (QSPM) applied to aretail computer store. The Coastal Business Journal, 8, 42-52

Kusumadewi, S., Hartati, S., Harjoko, A., Wardoyo, R., 2006. Fuzzy Multi-Atribut Decision Making (Fuzzy MADM). Yogyakarta: Graha Ilmu

Lerner, A.L., 1999. College of Business Administration and Economics, Research Associate, California State University, Northridge 
Madi, E.N., Osman, A., 2011. Fuzzy TOPSIS method in the Selection of Investment Boards by Incorporating Operational Risk. Proceding of the World Congress on Engineering. Vol.1

McNamara, C., 2011. Basic Overview of Various Strategic Planning Models, adapted from Field Guide to Nonprofit Strategic Planning and Facilitation, downloaded on 26/11/2011 from http://managementhelp.org/strategicplanning/mod els.html

Nasab, H.H., Milani, A.S., 2012. An improvement of quantitative strategic planning matrix using multiple criteria decision making and fuzzy numbers. Applied Soft Computing 12, 2246-2253

Rouhani, S., Mehdi, G., Mostafa, J., 2012. Evaluation model of business intelligence for enterprise system using fuzzy TOPSIS. Expert Systems with Applications 39, 3764-3771.
Ross, T.J., 2005. Fuzzy Logic for Planning and Decision Making, Kluwer Academic Press,Inc.

Shawyun,T., 2010. Developing and Actioning Strategic Planning in Higher Education Institutions, Thailand : Assumption University Press

Shojaie, M.R., Salili, S., Behrooz, A., 2012. Strategy formulation of saam higher education institution using SWOT and QSPM methodology. Journal of Applied Sciences Research, Vol. 8(7): 3329-3334

Wang, Y.M., Elhag, T.M.S., 2006, Fuzzy TOPSIS method based on Alpha Level Sets with an Application to Bridge Risk Assessment. Expert System with Applications, 31, 309-319

Zadeh, L.A., 1965. Fuzzy sets. Information and Control, Vol. 8, No.3, 338-358. 
Tabel 3. Nilai AS dari setiap kriteria

\begin{tabular}{llllllllllllllllllll}
\hline & \multicolumn{10}{l}{ Kriteria } & \multicolumn{11}{c}{ Strategi } & C1 & C2 & C3 & C4 & C5 & C6 & C7 & C8 & C9 & C11 & C12 & C13 & C14 & C15 & C16 & C17 & C18 & C19 \\
\hline Strategi 1 & TM & AM & CM & SM & TAR & TM & TM & AM & CM & TM & AM & CM & TM & SM & TAR & TM & CM & AM \\
Strategi 2 & AM & TM & CM & TAR & TM & AM & TM & TM & CM & TM & CM & AM & AM & TM & CM & AM & TM & AM \\
Strategi 3 & TM & TAR & AM & SM & CM & AM & CM & TM & AM & AM & CM & SM & TM & TM & AM & CM & SM & AM \\
Strategi 4 & SM & TAR & AM & SM & TM & TM & AM & CM & CM & SM & TM & TM & AM & SM & AM & TM & AM & CM \\
\hline
\end{tabular}

Tabel 4. Matriks keputusan ternormalisasi

\begin{tabular}{|c|c|c|c|c|c|c|c|}
\hline Kriteria & $\mathrm{C} 1$ & $\mathrm{C} 2$ & \multicolumn{2}{|l|}{$\mathrm{C} 3$} & \multicolumn{2}{|l|}{$\mathrm{C} 4$} & $\mathrm{C} 5$ \\
\hline Strategi 1 & $(0.000,0.000,0.013)$ & $(0.000,0.014,0.027)$ & \multicolumn{2}{|c|}{$(0.014,0.029,0.043)$} & \multicolumn{2}{|c|}{$(0.03,0.045,0.06)$} & $(0.000,0.000,0.000)$ \\
\hline Strategi 2 & $(0.000,0.013,0.026)$ & $(0.000,0.000,0.014)$ & \multicolumn{2}{|c|}{$(0.014,0.029,0.043)$} & \multicolumn{2}{|c|}{$(0.000,0.000,0.000)$} & $(0.000,0.000,0.0 .12)$ \\
\hline Strategi 3 & $(0.000,0.000,0.013)$ & $(0.000,0.000,0.000)$ & \multicolumn{2}{|c|}{$(0.000,0.014,0.029)$} & \multicolumn{2}{|c|}{$(0.03,0.045,0.06)$} & $(0.012,0.024,0.036)$ \\
\hline \multirow[t]{2}{*}{ Strategi 4} & $(0.026,0.039,0.051)$ & $(0.000,0.000,0.000)$ & \multicolumn{2}{|c|}{$(0.000,0.014,0.029)$} & \multicolumn{2}{|c|}{$(0.03,0.045,0.06)$} & $(0.000,0.000,0.012)$ \\
\hline & $\mathrm{C} 6$ & $\mathrm{C} 7$ & \multicolumn{2}{|c|}{$\mathrm{C} 8$} & \multicolumn{2}{|c|}{$\mathrm{C} 9$} & $\mathrm{C} 10$ \\
\hline Strategi 1 & $(0.000,0.000,0.012)$ & $(0.000,0.000,0.011)$ & \multicolumn{2}{|c|}{$(0.000,0.011,0.023)$} & \multicolumn{2}{|c|}{$(0.011,0.021,0.032)$} & $(0.000,0.014,0.027)$ \\
\hline Strategi 2 & $(0.000,0.012,0.024)$ & $(0.000,0.000,0.011$ & $(0.000,0.000,0$. & $.011)$ & $(0.011,0.021$, & $0.032)$ & $(0.000,0.014,0.027)$ \\
\hline Strategi 3 & $(0.000,0,012,0.024)$ & $0.011,0.023,0.034)$ & $(0.000,0.000,0$. & $.011)$ & $(0.000,0.011$, & $0.021)$ & $(0.000,0.000,0.014)$ \\
\hline Strategi 4 & $(0.000,0.000,0.012)$ & $(0.000,0.011,0.023$ & $(0.011,0.023,0$. & .034) & $(0.011,0.021$, & $.032)$ & $(0.000,0.000,0.014)$ \\
\hline & $\mathrm{C} 11$ & $\mathrm{C} 12$ & $\mathrm{C} 13$ & & $\mathrm{C} 14$ & & $\mathrm{C} 15$ \\
\hline Strategi 1 & $(0.000,0.000,0.014)$ & $(0.000,0.013,0.026$ & $(0.012,0.024,0$. & .036) & $(0.000,0.000$, & $.015)$ & $(0.026,0.039,0.051)$ \\
\hline Strategi 2 & $(0.000,0.000,0.014)$ & $(0.013,0.026,0.039$ & $(0.000,0.012,0$. & .024) & $(0.000,0.015$, & $.03)$ & $(0.000,0.000,0.013)$ \\
\hline Strategi 3 & $(0.000,0.014,0.029)$ & $(0.013,0.026,0.039$ & $(0.024,0.036,0$. & .048) & $(0.000,0.000$, & $.015)$ & $(0.000,0.000,0.013)$ \\
\hline Strategi 4 & $(0.029,0.043,0.057)$ & $(0.000,0.000,0.013$ & $(0.000,0.000,0$. & .012) & $(0.000,0.015$, & $.03)$ & $(0.026,0.039,0.051)$ \\
\hline & $\mathrm{C} 16$ & $\mathrm{C} 17$ & $\mathrm{C} 18$ & & $\mathrm{C} 19$ & & \\
\hline Strategi 1 & $(0.000,0.000,0.000)$ & $(0.000,0.000,0.015$ & $(0.12,0.024,0.0$ & 36) & $(0.000,0.015$, & $.03)$ & \\
\hline Strategi 2 & $(0.014,0.027,0.041)$ & $(0.000,0.015,0.03)$ & $(0.000,0.000,0$. & .012) & $(0.000,0.015$, & $.03)$ & \\
\hline Strategi 3 & $(0.000,0.014,0.027)$ & $(0.015,0.03,0.045)$ & $(0.024,0.036,0$. & .048) & $(0.000,0.015$, & $.03)$ & \\
\hline Strategi 4 & $(0.000,0.014,0.027)$ & $(0.000,0.000,0.015$ & $(0.000,0.012,0$. & .024) & $(0.015,0.03,0$. & 045) & \\
\hline Tabel 5. & Solusi Ideal & & & & & & \\
\hline Kriteria & $\mathrm{C} 1$ & $\mathrm{C} 2$ & $\mathrm{C} 3$ & & $\mathrm{C} 4$ & & $\mathrm{C} 5$ \\
\hline $\mathrm{A}^{*}$ & $(0.026,0.039,0.051)$ & $(0.000,0.014,0.027)$ & $(0.014,0.029,0.043)$ & $(0.0$ & $0.045,0.06)$ & $(0.01$ & $, 0.024,0.036)$ \\
\hline A- & $(0.000,0.000,0.013)$ & $(0.000,0.000,0.000)$ & $(0.000,0.014,0.029)$ & $(0.0$ & $, 0.000,0.000)$ & $(0.00$ & $, 0.000,0.000)$ \\
\hline & $\mathrm{C} 6$ & $\mathrm{C} 7$ & $\mathrm{C} 8$ & & $\mathrm{C} 9$ & & $\mathrm{C} 10$ \\
\hline$A^{*}$ & $(0.000,0,012,0.024)$ & $0.011,0.023,0.034)$ & $(0.011,0.023,0.034)$ & $(0.0$ & $1,0.021,0.032)$ & $(0.00$ & $0.014,0.027)$ \\
\hline A- & $(0.000,0.000,0.012)$ & $(0.000,0.000,0.011)$ & $(0.000,0.000,0.011)$ & $(0.0$ & $, 0.011,0.021)$ & $(0.00$ & $, 0.000,0.014)$ \\
\hline & $\mathrm{C} 11$ & $\mathrm{C} 12$ & $\mathrm{C} 13$ & & $\mathrm{C} 14$ & & $\mathrm{C} 15$ \\
\hline$A^{*}$ & $(0.029,0.043,0.057)$ & $(0.013,0.026,0.039)$ & $(0.024,0.036,0.048)$ & $(0.0)$ & $, 0.015,0.03)$ & $(0.026$ & $0.039,0.051)$ \\
\hline A- & $(0.000,0.000,0.014)$ & $(0.000,0.000,0.013)$ & $(0.000,0.000,0.012)$ & $(0.0$ & $, 0.000,0.015)$ & $(0.00$ & $, 0.000,0.013)$ \\
\hline & $\mathrm{C} 16$ & $\mathrm{C} 17$ & $\mathrm{C} 18$ & & C19 & & \\
\hline $\mathrm{A}^{*}$ & $(0.014,0.027,0.041)$ & $(0.015,0.03,0.045)$ & $(0.024,0.036,0.048)$ & $(0.0$ & $5,0.03,0.045)$ & & \\
\hline A- & $(0.000,0.000,0.000)$ & $(0.000,0.000,0.015)$ & $(0.000,0.000,0.012)$ & & $, 0.015,0.03)$ & & \\
\hline
\end{tabular}

